\title{
Different Activation Mechanisms of Excitatory Networks in the Rat Oculomotor Integrators for Vertical and Horizontal Gaze Holding
}

\author{
(1) Yasuhiko Saito and Taketoshi Sugimura
}

https://doi.org/10.1523/ENEURO.0364-19.2019

Department of Neurophysiology, Nara Medical University, Kashihara 634-8521, Japan

\section{Visual Abstract}

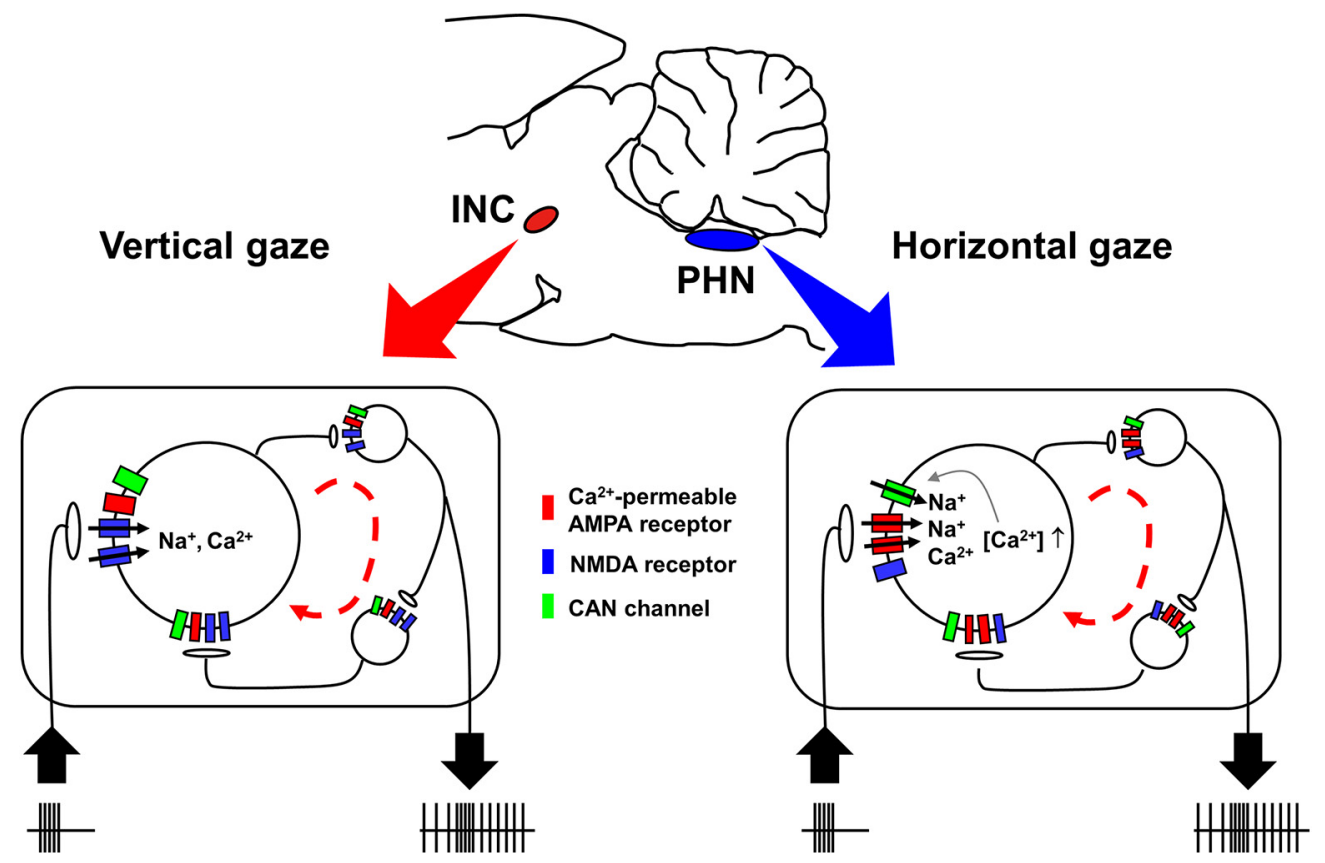

Gaze holding in the horizontal and vertical directions is separately controlled via the oculomotor neural integrators, the prepositus hypoglossi nucleus (PHN) and the interstitial nucleus of Cajal (INC), respectively. Our previous in vitro studies demonstrated that transient, high-frequency local stimulation of the PHN and the INC increased

\section{Significance Statement}

Position signals necessary for gaze holding are produced from velocity signals by mathematical integration via brainstem oculomotor integrators, which are separated into horizontal and vertical integrators. Although excitatory networks in the integrators are essential for their functions, the mechanisms of sustained activation in their networks have not been clarified. This study reports that the activation of excitatory networks in the horizontal integrator is mediated predominantly via $\mathrm{Ca}^{2+}$-permeable AMPA receptors and $\mathrm{Ca}^{2+}$-activated nonselective cation channels, while their activation in the vertical integrator is mediated predominantly via NMDA receptors. This result strongly suggests that excitatory networks are activated via different synaptic mechanisms between horizontal and vertical integrators. 
the frequency of spontaneous EPSCs that lasted for several seconds. The sustained EPSC response of PHN neurons was attributed to the activation of local excitatory networks primarily mediated via $\mathrm{Ca}^{2+}$-permeable AMPA (CP-AMPA) receptors and $\mathrm{Ca}^{2+}$-activated nonselective cation (CAN) channels. However, the contribution of CP-AMPA receptors to the activation of INC excitatory networks appeared to be small. In this study, we clarified the mechanisms of excitatory network activation in the PHN and INC using whole-cell recordings in rat brainstem slices. Although physiological and histological analyses showed that neurons that expressed CPAMPA receptors existed not only in the PHN but also in the INC, the effect of a CP-AMPA receptor antagonist on the sustained EPSC response was significantly weaker in INC neurons than in PHN neurons. Meanwhile, the effect of an NMDA receptor antagonist on the sustained EPSC response was significantly stronger in INC neurons than in PHN neurons. Furthermore, the current and the charge transfer mediated via NMDA receptors were significantly larger in INC neurons than in PHN neurons. These results strongly suggest that these excitatory networks are activated via different synaptic mechanisms: a CP-AMPA receptor and CAN channel-dependent mechanism and an NMDA receptor-dependent mechanism in horizontal and vertical integrators, respectively.

Key words: excitatory network; gaze holding; integrator; rat; slice patch clamp; synaptic mechanism

\section{Introduction}

The visual system does not have a high temporal resolution, and, therefore, holding the eye on a visual target for a certain amount of time is necessary for effective operation of the system. The function of gaze holding is executed primarily by an oculomotor neural integrator that converts transient burst signals that are proportional to eye or head velocity into sustained signals that are proportional to eye position (Skavenski and Robinson, 1973; Robinson, 1975, 1989; Fukushima, 1987, 1991; Fukushima et al., 1992; Fukushima and Kaneko, 1995; Moschovakis, 1997; Leigh and Zee, 2015). Although the generation of sustained signals necessary for gaze holding is attributed to neural network mechanisms, such as positive feedback excitation through mutual inhibition and/or recurrent excitation (Cannon et al., 1983; Galiana and Outerbridge, 1984; Cannon and Robinson, 1985; Draye et al., 1997; Arnold and Robinson, 1997; Seung et al., 2000), there are few experimental studies on the synaptic mechanisms employed to produce sustained signals in the mammalian neural integrator (NavarroLópez et al., 2004, 2005; Joshua and Lisberger 2015).

Horizontal gaze holding and vertical gaze holding are separately controlled by different oculomotor neural integrators, the prepositus hypoglossi nucleus $(\mathrm{PHN})$ and the interstitial nucleus of Cajal (INC), respectively (Fukushima, 1987, 1991; Fukushima et al., 1992; Fukushima and

Received September 11, 2019; accepted December 9, 2019; First published December 18, 2019.

The authors declare no competing financial interests.

Author contributions: Y.S. designed research; Y.S. and T.S. performed research; Y.S. and T.S. contributed unpublished reagents/analytic tools; Y.S. and T.S. analyzed data; Y.S. wrote the paper.

This work was supported by Japan Society for the Promotion of Science KAKENHI Grant 18K06524.

Acknowledgments: We thank the members of our laboratory for technical assistance and comments. We also thank the staff of the Institutes of Experimental Animal Research in Nara Medical Universities for technical support.

Correspondence should be addressed to Yasuhiko Saito at Syasu@naramed-u.ac.jp.

https://doi.org/10.1523/ENEURO.0364-19.2019

Copyright (C) 2020 Saito and Sugimura

This is an open-access article distributed under the terms of the Creative Commons Attribution 4.0 International license, which permits unrestricted use, distribution and reproduction in any medium provided that the original work is properly attributed.
Kaneko, 1995; Moschovakis, 1997; Leigh and Zee, 2015). We previously showed that under a blockade of inhibitory synaptic transmission, the application of a transient $(0.2$ s), high-frequency $(100 \mathrm{~Hz})$ electrical stimulation to a nearby site of a recorded PHN neuron induced an increase in the frequency of spontaneous EPSCs that lasted for several seconds (Saito and Yanagawa, 2010). This result indicates the presence of local excitatory networks in the PHN, which maintain sustained activity responsible for the generation of eye position signals. Pharmacological analyses have indicated that the sustained EPSC response is attributed preferentially to the activation of $\mathrm{Ca}^{2+}$-permeable AMPA (CP-AMPA) receptors and $\mathrm{Ca}^{2+}$-activated nonselective cation (CAN) channels of PHN neurons.

In contrast to the accumulating findings regarding the $\mathrm{PHN}$, there has been no report regarding the local networks in the INC. In our recent study (Saito et al., 2017), we examined excitatory networks in the INC by using the same experimental procedure used in the PHN study and found that the sustained EPSC responses also occurred in the INC. However, the effect of a CP-AMPA receptor antagonist on the sustained EPSC response was significantly smaller in the INC than in the PHN. These results suggest that the excitatory networks responsible for the sustained EPSC response are also present in the INC; however, the activation mechanism of the INC networks differs from the CP-AMPA receptor-dependent mechanism used in the PHN. In this study, we clarified the synaptic mechanisms preferential to the activation of excitatory networks in the PHN and the INC using whole-cell recordings in rat brainstem slices.

\section{Materials and Methods}

All experimental procedures were approved by the Animal Care Committee of Nara Medical University, and the experiments were conducted in accordance with the guidelines outlined by the US National Institutes of Health regarding the care and use of animals for experimental research. Although our previous studies were performed in slice preparations obtained from Wistar rats (Saito and Yanagawa, 2010; Saito et al., 2017), we used slices obtained from Long-Evans rats of either sex in this study because pigmented rats have higher visual acuity than 
albino rats (Birch and Jacobs, 1979; Prusky et al., 2002). A total of 30 Long-Evans rats (18-21 postnatal days old) were used in this study.

\section{Slice preparation and whole-cell recording}

The slice preparation and whole-cell patch-clamp recording procedures were similar to those described previously (Saito and Yanagawa, 2010; Saito et al., 2017). Briefly, the rat was deeply anesthetized with isoflurane and decapitated. The adequacy of the depth of anesthesia was judged by the absence of reflex movements to toe pinches. Frontal brain slices that included the INC or the PHN were cut using a Microslicer (Pro 7, Dosaka EM) in ice-cold sucrose solution containing the following (in $\mathrm{mM}$ ): 234 sucrose, $2.5 \mathrm{KCl}, 1.25 \mathrm{NaH}_{2} \mathrm{PO}_{4}, 10 \mathrm{MgSO}_{4}, 0.5$ $\mathrm{CaCl}_{2}, 26 \mathrm{NaHCO}_{3}$, and 11 glucose, bubbled with $95 \% \mathrm{O}_{2}$ and $5 \% \mathrm{CO}_{2}$. The thicknesses of the slices were $400 \mu \mathrm{m}$ for the recording of sustained EPSC responses and 250 $\mu \mathrm{m}$ for recordings of current responses to the local application of agonists. The slices were recovered in an interface-type chamber perfused with an extracellular solution containing the following (in $\mathrm{mm}$ ): $125 \mathrm{NaCl}, 2.5 \mathrm{KCl}$, $2 \mathrm{CaCl}_{2}, 1 \mathrm{MgCl}_{2}, 1.25 \mathrm{NaH}_{2} \mathrm{PO}_{4}, 26 \mathrm{NaHCO}_{3}$ and 25 glucose, aerated with $95 \% \mathrm{O}_{2}$ and $5 \% \mathrm{CO}_{2}, \mathrm{pH} 7.4$, at $33^{\circ} \mathrm{C}$ for $1 \mathrm{~h}$. After recovery, the slices were incubated in an aerated extracellular solution at room temperature. For recordings, each slice was placed in a submerged recording chamber on an upright microscope (model DM LFS, Leica Microsystems; RRID:SCR_008960) and continuously perfused with the extracellular solution at a rate of 3 $\mathrm{ml} / \mathrm{min}$. The bath temperature was maintained at $30-32^{\circ} \mathrm{C}$ using an in-line heater (SH-27A, Warner Instruments). Whole-cell recordings were performed using an EPC-8 patch-clamp amplifier (HEKA), and the data were acquired using a pClamp9 system (Molecular Devices). The internal solution contained the following (in $\mathrm{mM}$ ): $145 \mathrm{Cs}$ gluconate, $5 \mathrm{CsCl}$, 0.2 EGTA, $2 \mathrm{Mg}$-ATP, 0.3 Na-GTP, 10 HEPES, 0.1 spermine, and 5 lidocaine $N$-ethyl bromide $(\mathrm{QX}-314)$ at $\mathrm{pH} 7.3$, and its osmolarity was $280-290$ $\mathrm{mOsm} / \mathrm{L}$. The resistance of patch electrodes was 4-8 $\mathrm{M} \Omega$ in the bath solution. Current signals were low-pass filtered at $1 \mathrm{kHz}$ and digitized at $2-5 \mathrm{kHz}$. The signals were corrected for the measured liquid junction potential $(-10$ $\mathrm{mV}$ ). EPSC responses to high-frequency stimulation (burst stimulation) were recorded under a blockade of inhibitory synaptic transmissions by applying $20 \mu \mathrm{M}$ strychnine, an antagonist of glycine receptors, and 100 $\mu \mathrm{M}$ picrotoxin, an antagonist of $\mathrm{GABA}_{\mathrm{A}}$ receptors. The membrane potential of a recorded neuron was held at $-75 \mathrm{mV}$ during the recordings. Burst stimulation with 20 cathodal square-wave pulses (40-50 $\mu \mathrm{A}, 100 \mu \mathrm{s}$ in duration) was applied at $30 \mathrm{~s}$ intervals in the vicinity of a recorded neuron using a glass micropipette that was filled with the extracellular solution. The site where the current response of the neuron was the largest was determined as an appropriate stimulation site. In this experiment, the distance between a recorded neuron and the stimulation electrode was $40-120 \mu \mathrm{m}$. Three current traces were recorded from each neuron. The current responses of AMPA receptors and NMDA receptors were investigated by local application of $1 \mathrm{~mm}$ kainic acid (KA) or $1 \mathrm{~mm}$ NMDA to the soma of a recorded neuron, respectively. Different micropipettes were filled with KA or NMDA and were applied separately via pressurized air (30 psi, 5-8 ms) using a pneumatic PicoPump (catalog \#PV820, WPI; RRID:SCR_008593). The tips of the micropipettes were maintained at the sites where the largest current responses were recorded. At the beginning of the recording, the reversal potential at which the application of KA induced no current deflection from baseline was determined. Thereafter, the current responses of AMPA receptors at holding potentials of -60 and $+40 \mathrm{mV}$ were recorded to determine the rectification index (RI; Ozawa et al., 1991). The current responses of AMPA and NMDA receptors were recorded at holding potentials of -70 and $+40 \mathrm{mV}$, respectively. To monitor the series resistance during the recordings, a short voltage pulse $(-10 \mathrm{mV}, 100$ $\mathrm{ms}$ ) was applied before agonist application. When the series resistance, which was routinely compensated by $60 \%$, changed by $>20 \%$ during the recordings, the data were discarded.

\section{Cobalt uptake}

To histologically determine the neurons that express CP-AMPA receptors, we performed a $\mathrm{Co}^{2+}$ uptake procedure according to the method of Shimshek et al. (2006). In brief, $400-\mu \mathrm{m}$-thick frontal slices were cut as described above. After the recovery of slices in the interface-type chamber, they were incubated in a low- $\mathrm{Na}^{+}$Krebs' solution with $0.5 \mu \mathrm{M}$ tetrodotoxin (TTX) and $50 \mu \mathrm{M}$ D-(-)-2amino-5-phosphonopentanoic acid (APV) for $15 \mathrm{~min}$. This Krebs' solution was composed of the following (in $\mathrm{mm}$ ): 135 sucrose, $50 \mathrm{NaCl}, 2.5 \mathrm{KCl}, 1.25 \mathrm{NaH}_{2} \mathrm{PO}_{4}, 2 \mathrm{MgCl}_{2}$, $0.5 \mathrm{CaCl}_{2}, 26 \mathrm{NaHCO}_{3}$, and 25 glucose. As a negative control, slices were incubated in Krebs' solution containing TTX, APV, and $20 \mu \mathrm{M}$ 2,3-Dioxo-6-nitro-1,2,3,4tetrahydrobenzo[f]quinoxaline-7-sulfonamide (NBQX) disodium salt. The slices were transferred to Krebs' solution containing TTX, APV, $20 \mu \mathrm{M} \mathrm{KA}$, and $1.5 \mathrm{mM} \mathrm{CoCl}_{2}$, and incubated for $20 \mathrm{~min}$. After $\mathrm{KA}$-induced $\mathrm{CO}_{2}{ }^{+}$loading, the slices were incubated in Krebs' solution without divalent ions containing $5 \mathrm{~mm}$ EDTA for $10 \mathrm{~min}$ and further washed with Krebs' solution without divalent ions. Intracellular $\mathrm{Co}^{2+}$ was precipitated by incubating in Krebs' solution without divalent ions containing $0.12 \% \mathrm{NH}_{4} \mathrm{~S}$ for $5 \mathrm{~min}$ and washing with Krebs' solution without divalent ions. Thereafter, the slices were fixed with $4 \%$ paraformaldehyde in $0.1 \mathrm{M}$ PBS and kept in the fixative for $1-3 \mathrm{~d}$ at $4^{\circ} \mathrm{C}$. The slices were further cut to a thickness of $50 \mu \mathrm{m}$ with a sliding microtome (TU-213, Yamato Kohki). For silver intensification, the slices were incubated in $\mathrm{Na}_{2} \mathrm{WO}_{4}(2 \%$ in water) for $10 \mathrm{~min}$ and then in a $20 \mathrm{ml}$ developer solution (16 ml of $\mathrm{AgNO}_{3}$ solution containing $1 \%$ Triton X-100, $7.5 \% \mathrm{CH}_{3} \mathrm{COOH}, 30.3 \mathrm{~mm}$ Na-acetate, $2.94 \mathrm{~mm}$ AgNO3, 2 $\mathrm{ml}$ of $5 \% \mathrm{Na}_{2} \mathrm{WO}_{4}$, and $2 \mathrm{ml}$ of $0.25 \%$ ascorbic acid) in the dark for 7 min. The slices were washed with $\mathrm{Na}_{2} \mathrm{WO}_{4}$, dried, and coverslipped with Entellan (Merck; RRID: SCR_001287). Labeled neurons were observed using a light microscope (model BX60, Olympus). 


\section{Drugs}

NMDA, KA, APV, 1-naphthyl acetyl spermine (NAS), and NBQX were purchased from Tocris Bioscience (RRID: SCR_003689); strychnine hydrochloride, flufenamic acid (FFA), and QX-314 were purchased from Sigma-Aldrich (RRID:SCR_008988); $\mathrm{NH}_{4} \mathrm{~S}$ was purchased from Strem Chemicals; and other drugs were purchased from Wako Pure Chemical Industries (RRID:SCR_013651). The agonists and antagonists, with the exception of FFA, were dissolved in water (1000 times the final concentration) and stored as stock solutions at $-20^{\circ} \mathrm{C}$ before being diluted in the oxygenated extracellular solution. FFA stock was prepared in DMSO (2000 times the final concentration). KA and NMDA used for local application were stored at a concentration of $20 \mathrm{~mm}$ dissolved in water and were diluted to $1 \mathrm{~mm}$ with the extracellular solution before use.

\section{Data analysis}

Offline analysis was performed with AxoGraph X software (RRID:SCR_014284) and KaleidaGraph (RRID: SCR_014980). EPSCs were determined when the peak of the inward current was larger than three times the SD of the baseline noise before burst stimulation. The duration of the increased EPSC frequency was defined as the time period from when burst stimulation was terminated to when the averaged value of three adjacent bins (corresponding to $300 \mathrm{~ms}$ ) became equal to or smaller than the average baseline EPSC frequency before burst stimulation. The EPSC frequency after burst stimulation was measured from recordings of $1 \mathrm{~s}$ after burst stimulation. The RI was calculated using the formula: $\mathrm{RI}=\left(I_{+40} /+40\right) /$ $\left(I_{-60} /-60\right)$, where $I_{+40}$ and $I_{-60}$ represent the amplitude of $\mathrm{KA}$-induced currents at membrane potentials of +40 and $-60 \mathrm{mV}$ from the reversal potential, respectively. The rectification properties are approximately separated by an $\mathrm{RI}$ value of $1 ; \mathrm{RI}<1$ and $\mathrm{RI} \geq 1$ indicate current responses with inwardly and outwardly rectifying properties, respectively (Ozawa et al., 1991). The charge transfer of NMDA receptor-mediated currents was estimated as the area of the currents for $10 \mathrm{~s}$ following the puff application. The charge transfer was normalized by the input capacitance that was estimated based on the current induced by a 10 $\mathrm{mV}$ voltage step from a holding potential of $-70 \mathrm{mV}$. All values are shown as the mean $\pm S D$, and the error bars in the figures represent the SD. The number $(n)$ refers to the number of neurons analyzed, unless otherwise noted. The statistical analysis was performed using unpaired or paired Student's $t$ tests for normally distributed data. For data that did not follow a normal distribution, the MannWhitney test and the Wilcoxon signed-rank test were used for unpaired and paired data, respectively. Differences in the distributions between the groups were tested using the Kolmogorov-Smirnov test. Data normality was determined using the Shapiro-Wilk test. These analyses were performed using StatView software (version 5.0, Hulinks) and JMP software (version 6.0.2; RRID: SCR_014242). A post hoc power analysis was performed using G*Power3 software (version 3.1.9.4, http://www.gpower.hhu.de/; RRID:SCR_013726; Faul et al., 2007). Statistical significance was determined at the level of $p<$
0.05 . The results of the statistical analyses are shown in Table 1.

\section{Results}

Before investigating the mechanisms of INC excitatory network activation, we revalidated that CP-AMPA receptors had a weaker contribution to the sustained EPSC responses of INC neurons than PHN neurons in LongEvans rats. Figure 1, $A$ and $B$, shows EPSC responses of a PHN neuron and an INC neuron, respectively, to burst stimulation before (Fig. 1A1,B1) and during (Fig. 1A2,B2) the application of $50 \mu \mathrm{M}$ NAS, an open-channel blocker of CP-AMPA receptors (Asami et al., 1989; Takazawa et al., 1996; Koike et al., 1997; Twomey et al., 2018). The burst stimulation (Fig. $1 A, B$, arrow) induced an increase in the frequency of spontaneous EPSCs that lasted for several seconds in the PHN and INC neurons. Although NAS application significantly reduced the duration of the sustained EPSC responses and the EPSC frequency for $1 \mathrm{~s}$ after burst stimulation in PHN neurons (Table 1, A, C) and INC neurons (Table 1, B, D), marked reductions were observed in the PHN neurons, while only slight reductions were observed in the INC neurons. INC neurons exhibited significantly smaller reductions in EPSC duration and frequency than PHN neurons (Table 1, E, F). These results confirm the finding that CP-AMPA receptors strongly participate in the activation of PHN networks but weakly participate in the activation of INC networks. Neurons that express CP-AMPA receptors show an inwardly rectifying current response property and are estimated according to the RI values (lino et al., 1990; Hume et al., 1991; Burnashev et al., 1992; Ozawa and lino, 1993; for review, see Jonas and Burnashev, 1995; Ozawa et al., 1998). We therefore investigated the distribution of neurons that expressed CP-AMPA receptors by estimating the RI from the current responses of PHN and INC neurons to air-puff application of $1 \mathrm{mM} \mathrm{KA}$, which is a nondesensitizing agonist of AMPA receptors (Kiskin et al., 1986; Patneau and Mayer, 1991), at holding potentials of -60 and $+40 \mathrm{mV}$. Figure 1D1 shows current responses of a neuron, for which the amplitude of current at $+40 \mathrm{mV}$ was comparable to that at $-60 \mathrm{mV}$. The RI value of this neuron was $>1$ $(R I=1.28)$, indicating that the current responses of this neuron exhibit an outwardly rectifying property. On the other hand, Figure $1 D 2$ shows the current responses of another neuron, for which the amplitude of current at +40 $\mathrm{mV}$ was much smaller than that at $-60 \mathrm{mV}(\mathrm{RI}=0.67$; Fig. $1 D 2)$, indicating that the current responses of this neuron exhibited an inwardly rectifying property. Histograms of PHN and INC neurons were plotted according to the RI values (Fig. 1D3,4). The proportion of neurons that exhibited $\mathrm{RI}<1$ (open bars) was larger in the PHN $(70.8 \%, n=$ 48) than in the INC $(53.3 \%, n=45)$, and the neuronal distributions based on the RI significantly differed between the PHN and the INC (Table 1, G). This result indicates that more neurons expressing CP-AMPA receptors are present in the PHN than in the INC. To further clarify the presence of neurons that express CP-AMPA receptors both in the PHN and the INC, we performed a KA-induced cobalt uptake experiment (Pruss et al., 1991; 
Table 1: Statistical test

\begin{tabular}{|c|c|c|c|c|c|c|c|}
\hline Label & Parameter (unit) & Bivariate & Cell\# & Mean & SD & $\begin{array}{c}\text { Distribution, } \boldsymbol{p} \text { value } \\
\text { (type of test) }\end{array}$ & $\begin{array}{c}\text { Power } \\
(\alpha=0.05)\end{array}$ \\
\hline A & $\begin{array}{l}\text { Duration of PHN neurons } \\
\text { (s) }\end{array}$ & $\begin{array}{l}\text { Control } \\
\text { NAS }\end{array}$ & $\begin{array}{l}8 \\
8\end{array}$ & $\begin{array}{l}2.6 \\
0.9\end{array}$ & $\begin{array}{l}0.8 \\
0.3\end{array}$ & $\begin{array}{l}\text { Normal, } p=0.0008 \\
\text { (paired } t \text { test) }\end{array}$ & 1.000 \\
\hline B & $\begin{array}{l}\text { Duration of INC neurons } \\
\text { (s) }\end{array}$ & $\begin{array}{l}\text { Control } \\
\text { NAS }\end{array}$ & $\begin{array}{l}8 \\
8\end{array}$ & $\begin{array}{l}2.1 \\
1.8\end{array}$ & $\begin{array}{l}0.6 \\
0.6\end{array}$ & $\begin{array}{l}\text { Non-normal, } p=0.00107 \\
\text { (Wilcoxon signed-rank test) }\end{array}$ & 1.000 \\
\hline C & $\begin{array}{l}\text { EPSC rate of PHN neurons } \\
\text { (event/s) }\end{array}$ & $\begin{array}{l}\text { Control } \\
\text { NAS }\end{array}$ & $\begin{array}{l}8 \\
8\end{array}$ & $\begin{array}{l}30.3 \\
16.0\end{array}$ & $\begin{array}{l}6.7 \\
8.5\end{array}$ & $\begin{array}{l}\text { Normal, } p=0.0005 \\
\text { (paired } t \text { test) }\end{array}$ & 1.000 \\
\hline D & $\begin{array}{l}\text { EPSC rate of INC neurons } \\
\text { (event/s) }\end{array}$ & $\begin{array}{l}\text { Control } \\
\text { NAS }\end{array}$ & $\begin{array}{l}8 \\
8\end{array}$ & $\begin{array}{l}32.1 \\
25.7\end{array}$ & $\begin{array}{l}13.6 \\
11.8\end{array}$ & $\begin{array}{l}\text { Normal, } p=0.0011 \\
\text { (paired } t \text { test) }\end{array}$ & 0.999 \\
\hline$E$ & $\begin{array}{l}\text { Reduction in duration } \\
\text { by NAS (\%) }\end{array}$ & $\begin{array}{l}\text { PHN } \\
\text { INC }\end{array}$ & $\begin{array}{l}8 \\
8\end{array}$ & $\begin{array}{l}62.2 \\
16.2\end{array}$ & $\begin{array}{l}15.4 \\
8.9\end{array}$ & $\begin{array}{l}\text { Non-normal, } p=0.0008 \\
\text { (Mann-Whitney test) }\end{array}$ & 1.000 \\
\hline $\mathrm{F}$ & $\begin{array}{l}\text { Reduction in EPSC rate } \\
\text { by NAS (\%) }\end{array}$ & $\begin{array}{l}\text { PHN } \\
\text { INC }\end{array}$ & $\begin{array}{l}8 \\
8\end{array}$ & $\begin{array}{l}48.3 \\
21.8\end{array}$ & $\begin{array}{l}21.4 \\
10.9\end{array}$ & $\begin{array}{l}\text { Normal, } p=0.0005 \\
\text { (unpaired } t \text { test) }\end{array}$ & 0.906 \\
\hline G & Distribution of RI & $\begin{array}{l}\text { PHN } \\
\text { INC }\end{array}$ & $\begin{array}{l}48 \\
45\end{array}$ & $\begin{array}{l}0.88 \\
1.00\end{array}$ & $\begin{array}{l}0.21 \\
0.21\end{array}$ & $\begin{array}{l}\text { Normal, } p=0.01 \\
\text { (unpaired } t \text { test) }\end{array}$ & 0.833 \\
\hline $\mathrm{H}$ & $\begin{array}{l}\text { Duration of PHN neurons } \\
\text { (s) }\end{array}$ & $\begin{array}{l}\text { Control } \\
\text { APV }\end{array}$ & $\begin{array}{l}10 \\
10\end{array}$ & $\begin{array}{l}2.1 \\
1.9\end{array}$ & $\begin{array}{l}0.8 \\
0.8\end{array}$ & $\begin{array}{l}\text { Non-normal, } p=0.1359 \\
\text { (Wilcoxon signed-rank test) }\end{array}$ & 0.524 \\
\hline I & $\begin{array}{l}\text { Duration of INC neurons } \\
\text { (s) }\end{array}$ & $\begin{array}{l}\text { Control } \\
\text { APV }\end{array}$ & $\begin{array}{l}10 \\
10\end{array}$ & $\begin{array}{l}1.7 \\
0.7\end{array}$ & $\begin{array}{l}0.4 \\
0.3\end{array}$ & $\begin{array}{l}\text { Normal, } p<0.0001 \\
\text { (paired } t \text { test) }\end{array}$ & 1.000 \\
\hline J & $\begin{array}{l}\text { EPSC rate of PHN neurons } \\
\text { (event/s) }\end{array}$ & $\begin{array}{l}\text { Control } \\
\text { APV }\end{array}$ & $\begin{array}{l}10 \\
10\end{array}$ & $\begin{array}{l}22.1 \\
19.8\end{array}$ & $\begin{array}{l}8.5 \\
8.1\end{array}$ & $\begin{array}{l}\text { Normal, } p=0.0594 \\
\text { (paired } t \text { test) }\end{array}$ & 0.637 \\
\hline K & $\begin{array}{l}\text { EPSC rate of INC neurons } \\
\text { (event/s) }\end{array}$ & $\begin{array}{l}\text { Control } \\
\text { APV }\end{array}$ & $\begin{array}{l}10 \\
10\end{array}$ & $\begin{array}{l}21.7 \\
14.6\end{array}$ & $\begin{array}{l}6.1 \\
5.3\end{array}$ & $\begin{array}{l}\text { Normal, } p=0.0004 \\
\text { (paired } t \text { test) }\end{array}$ & 1.000 \\
\hline L & $\begin{array}{l}\text { Reduction in duration } \\
\text { by APV (\%) }\end{array}$ & $\begin{array}{l}\text { PHN } \\
\text { INC }\end{array}$ & $\begin{array}{l}10 \\
10\end{array}$ & $\begin{array}{l}10.8 \\
57.6\end{array}$ & $\begin{array}{l}11.2 \\
13.1\end{array}$ & $\begin{array}{l}\text { Normal, } p<0.0001 \\
\text { (paired } t \text { test) }\end{array}$ & 1.000 \\
\hline M & $\begin{array}{l}\text { Reduction in EPSC rate } \\
\text { by APV (\%) }\end{array}$ & $\begin{array}{l}\text { PHN } \\
\text { INC }\end{array}$ & $\begin{array}{l}10 \\
10\end{array}$ & $\begin{array}{l}14.7 \\
33.2\end{array}$ & $\begin{array}{l}13.1 \\
14.2\end{array}$ & $\begin{array}{l}\text { Normal, } p=0.0071 \\
\text { (paired } t \text { test) }\end{array}$ & 0.899 \\
\hline $\mathrm{N}$ & NMDA/AMPA ratio & $\begin{array}{l}\mathrm{PHN} \\
\text { INC }\end{array}$ & $\begin{array}{l}44 \\
38\end{array}$ & $\begin{array}{l}0.56 \\
0.82\end{array}$ & $\begin{array}{l}0.45 \\
0.44\end{array}$ & $\begin{array}{l}\text { Non-normal, } p<0.0001 \\
\text { (Mann-Whitney test) }\end{array}$ & 0.841 \\
\hline $\mathrm{O}$ & $\begin{array}{l}\text { NMDA charge transfer } \\
(\mathrm{pC} / \mathrm{pF})\end{array}$ & $\begin{array}{l}\text { PHN } \\
\text { INC }\end{array}$ & $\begin{array}{l}44 \\
38\end{array}$ & $\begin{array}{l}11.8 \\
19.2\end{array}$ & $\begin{array}{l}5.6 \\
8.1\end{array}$ & $\begin{array}{l}\text { Non-normal, } p<0.0001 \\
\text { (Mann-Whitney test) }\end{array}$ & 0.999 \\
\hline$P$ & $\begin{array}{l}\text { Duration of PHN neurons } \\
\text { (s) }\end{array}$ & $\begin{array}{l}\text { Control } \\
\text { FFA }\end{array}$ & $\begin{array}{l}8 \\
8\end{array}$ & $\begin{array}{l}2.4 \\
1.2\end{array}$ & $\begin{array}{l}0.6 \\
0.5\end{array}$ & $\begin{array}{l}\text { Normal, } p=0.0031 \\
\text { (paired } t \text { test) }\end{array}$ & 0.990 \\
\hline Q & $\begin{array}{l}\text { Duration of INC neurons } \\
\text { (s) }\end{array}$ & $\begin{array}{l}\text { Control } \\
\text { FFA }\end{array}$ & $\begin{array}{l}8 \\
8\end{array}$ & $\begin{array}{l}2.7 \\
2.1\end{array}$ & $\begin{array}{l}0.7 \\
0.7\end{array}$ & $\begin{array}{l}\text { Non-normal, } p=0.0116 \\
\text { (Wilcoxon signed-rank test) }\end{array}$ & 0.963 \\
\hline $\mathrm{R}$ & $\begin{array}{l}\text { EPSC rate of PHN neurons } \\
\text { (event/s) }\end{array}$ & $\begin{array}{l}\text { Control } \\
\text { FFA }\end{array}$ & $\begin{array}{l}8 \\
8\end{array}$ & $\begin{array}{l}29.0 \\
14.3\end{array}$ & $\begin{array}{l}10.0 \\
4.8\end{array}$ & $\begin{array}{l}\text { Normal, } p=0.0081 \\
\text { (paired } t \text { test) }\end{array}$ & 0.948 \\
\hline S & $\begin{array}{l}\text { EPSC rate of INC neurons } \\
\text { (event/s) }\end{array}$ & $\begin{array}{l}\text { Control } \\
\text { FFA }\end{array}$ & $\begin{array}{l}8 \\
8\end{array}$ & $\begin{array}{l}26.3 \\
21.3\end{array}$ & $\begin{array}{l}6.7 \\
5.6\end{array}$ & $\begin{array}{l}\text { Normal, } p=0.0151 \\
\text { (paired } t \text { test) }\end{array}$ & 0.900 \\
\hline $\mathrm{T}$ & $\begin{array}{l}\text { Reduction in duration } \\
\text { by FFA }(\%)\end{array}$ & $\begin{array}{l}\text { PHN } \\
\text { INC }\end{array}$ & $\begin{array}{l}8 \\
8\end{array}$ & $\begin{array}{l}47.7 \\
22.0\end{array}$ & $\begin{array}{l}22.3 \\
13.3\end{array}$ & $\begin{array}{l}\text { Normal, } p=0.0143 \\
\text { (unpaired } t \text { test) }\end{array}$ & 0.844 \\
\hline U & $\begin{array}{l}\text { Reduction in EPSC rate } \\
\text { by FFA (\%) }\end{array}$ & $\begin{array}{l}\text { PHN } \\
\text { INC }\end{array}$ & $\begin{array}{l}8 \\
8\end{array}$ & $\begin{array}{l}46.1 \\
18.4\end{array}$ & $\begin{array}{l}21.5 \\
13.4\end{array}$ & $\begin{array}{l}\text { Normal, } p=0.008 \\
\text { (unpaired } t \text { test) }\end{array}$ & 0.902 \\
\hline
\end{tabular}

Engelman et al., 1999: Shimshek et al., 2006), in which neurons uptake and accumulate $\mathrm{Co}^{2+}$ during activation by KA. Using the $\mathrm{Co}^{2+}$ uptake procedure, darkly stained neurons were found to be scattered in the PHN and the INC (Fig. 1E, left), although neurons were not labeled in the presence of $20 \mu \mathrm{M}$ NBQX, an AMPA receptor antagonist (Fig. 1E, right). This result confirms the presence of neurons that express CP-AMPA receptors not only in the $\mathrm{PHN}$, but also in the INC.

Our previous study demonstrated that the sustained EPSC responses in the PHN were not significantly affected by APV, an NMDA receptor antagonist (Saito and Yanagawa, 2010). This finding was confirmed by the present study (Fig. 2A), in which the EPSC duration and frequency of PHN neurons were not significantly different before and after the application of APV (Fig. 2C1,D1, Table 1, H, J). However, when the effect of APV on the sustained EPSC responses was tested in INC neurons
(Fig. 2B), the EPSC duration and frequency were found to be significantly reduced in the presence of APV (Fig. $2 C 2, D 2$, Table 1, I, K). Significantly larger reductions in the EPSC duration and frequency were found in INC neurons than in PHN neurons (Table 1, L, M). These results suggest that NMDA receptors have a strong contribution to the activation of INC networks than to the activation of PHN networks.

Based on the stronger effect of APV on INC neurons, we next examined whether current responses mediated via NMDA receptors differed between PHN and INC neurons. To compare NMDA receptor-mediated currents, we analyzed the ratio of NMDA receptor-mediated currents to AMPA receptor-mediated currents (NMDA/AMPA ratio; Fig. $3 A, B)$. The NMDA/AMPA ratio of INC neurons was significantly higher than that of PHN neurons (Fig. $3 B$, Table $1, N$ ). In addition, the charge transfer mediated via NMDA receptors of INC neurons was signifi- 
A PHN

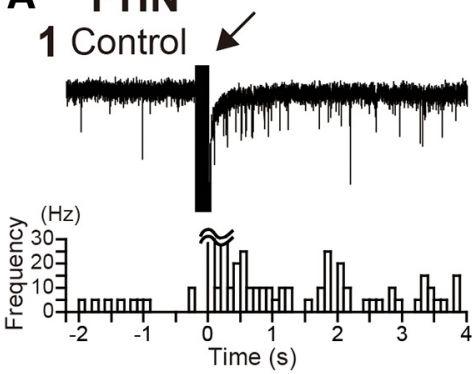

B INC

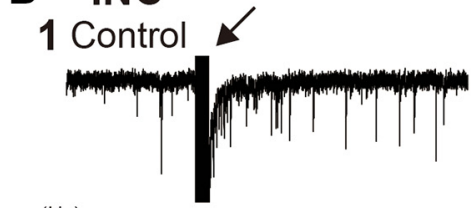

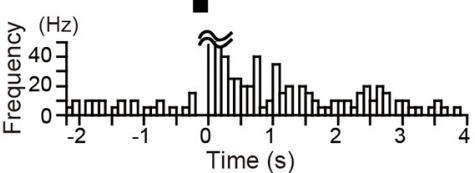
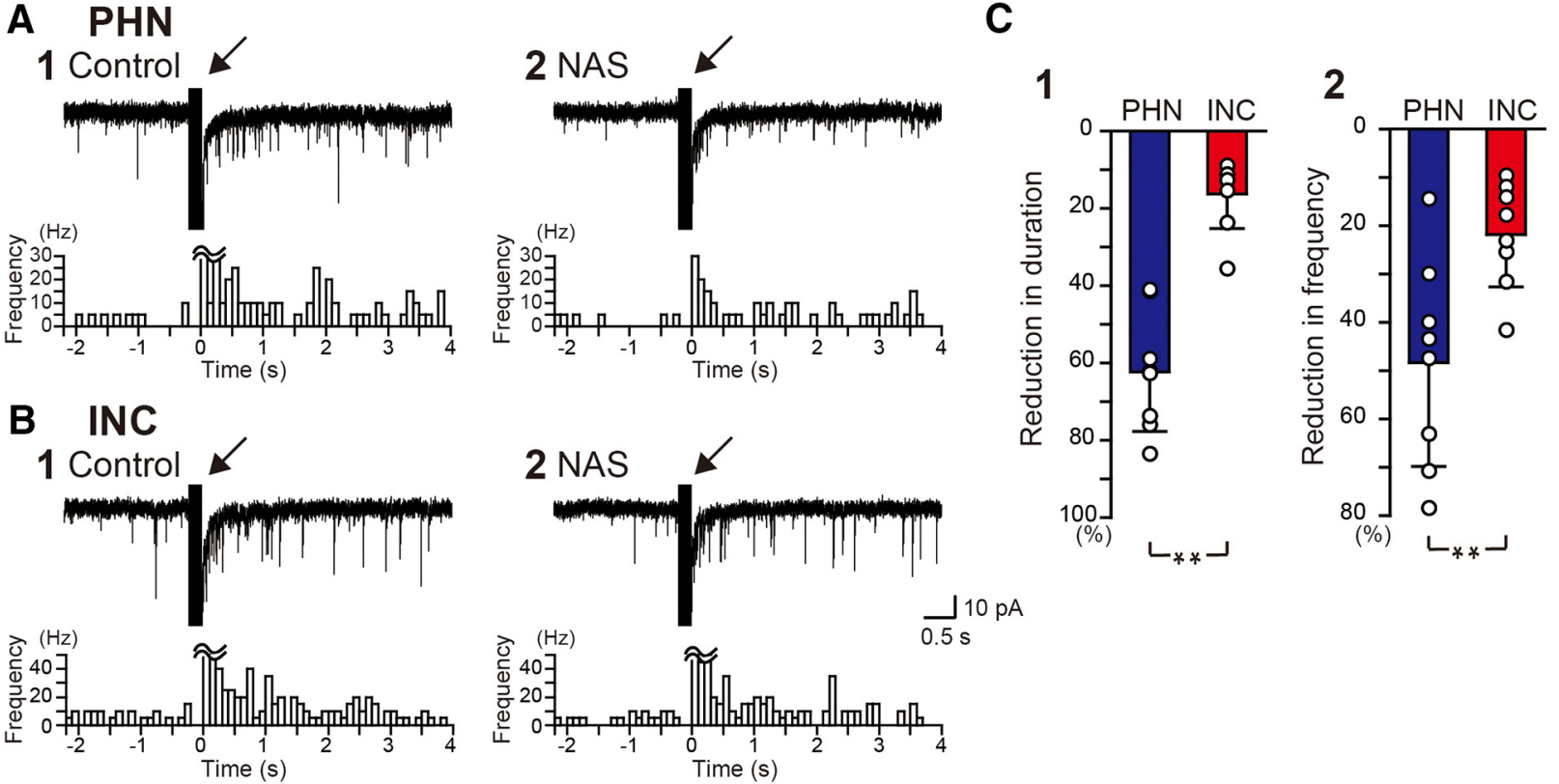

D

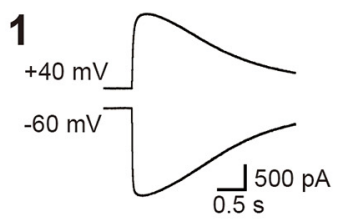

2

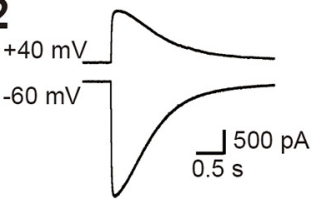

3. PHN

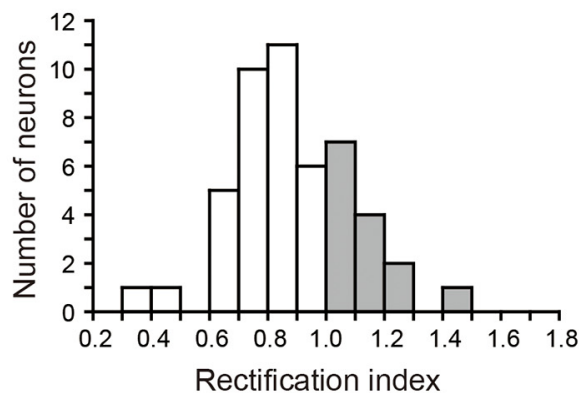

4. INC

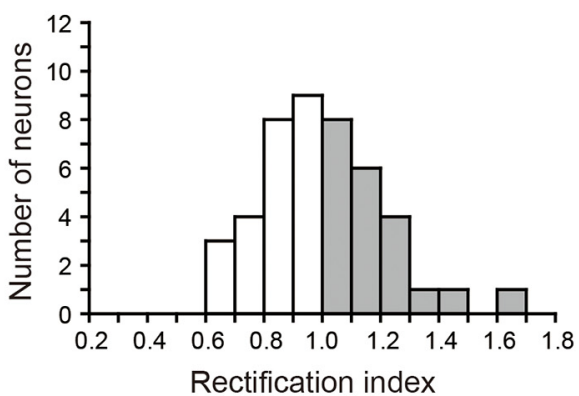

E

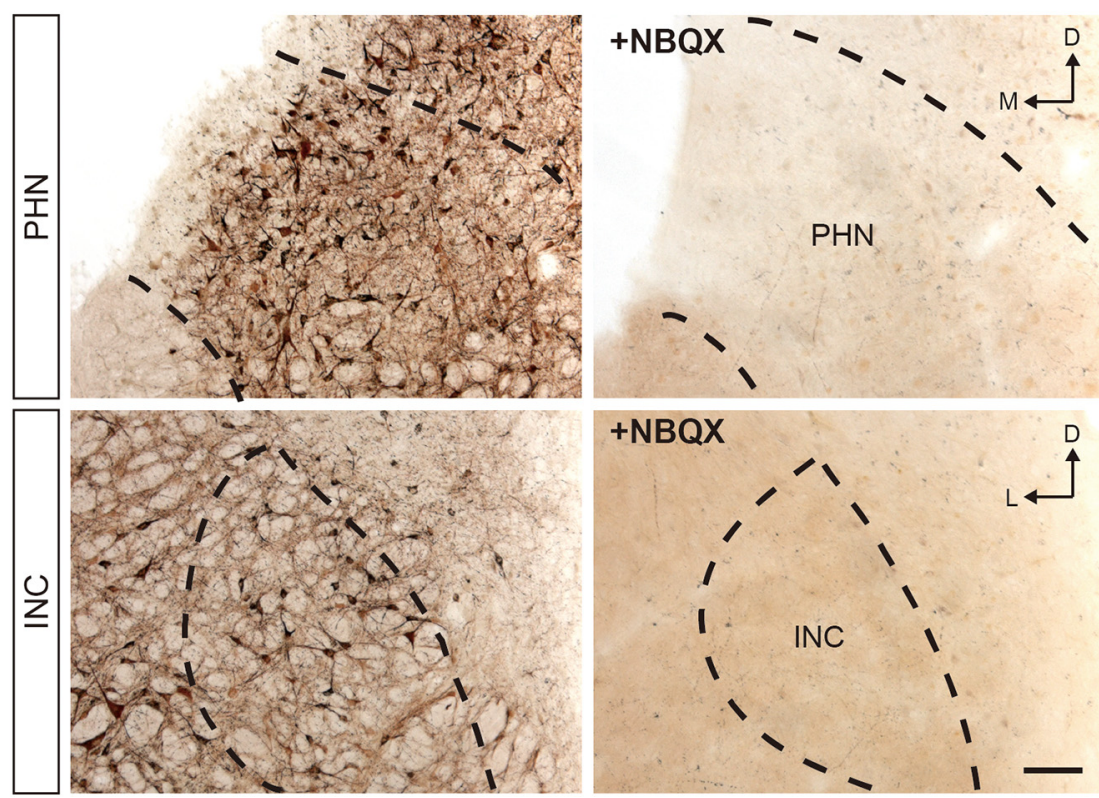

Figure 1. Difference in the expression of CP-AMPA receptors in PHN and INC neurons. $\boldsymbol{A}, \boldsymbol{B}$, EPSC responses of a PHN neuron $(\boldsymbol{A})$ and an INC neuron $(\boldsymbol{B})$ to burst stimulation before $(\boldsymbol{A 1}, \boldsymbol{B 1})$ and during $(\boldsymbol{A} 2, \boldsymbol{B 2})$ the application of $50 \mu \mathrm{M}$ NAS. The arrow indicates the artifact induced by the burst stimulation. Bottom, Histograms showing the averaged EPSC frequency against time. The width of the 


\section{continued}

histogram bins is $100 \mathrm{~ms}$. C1, C2, Comparisons of the percentage reduction in EPSC duration (C1) and frequency (C2) caused by NAS between PHN and INC neurons. Asterisks indicate a significant difference between groups $(* * p<0.01)$. D, Current responses of two different INC neurons $(\boldsymbol{D} 1, \boldsymbol{D} 2)$ to puff application of $20 \mathrm{~mm}$ kainate at holding potentials of -60 and $+40 \mathrm{mV}$. Histograms of PHN neurons $(D 3 ; n=48)$ and INC neurons $(\boldsymbol{D} 4 ; n=45)$ exhibiting different RI values. Gray bars indicate an RI $>1$. $\boldsymbol{E}$, Kainate-induced $\mathrm{Co}^{2+}$ uptake in the PHN (top) and the INC (bottom). Darkly stained cells indicate the cells that took $\mathrm{Co}^{2+}$ into their body via $\mathrm{Ca}^{2+}$-permeable AMPA receptors. Right panels show the negative control that was obtained in the presence of NBQX. The dashed lines indicate the approximate regions of the PHN and the INC.

cantly larger than that of PHN neurons (Fig. 3C, Table 1, O).

Our previous study showed that the application of FFA, a blocker of CAN channels, also reduced the sustained EPSC responses of PHN neurons (Saito and Yanagawa, 2010). This finding was confirmed by the present study (Fig. 4A), in which the EPSC duration and frequency of PHN neurons were significantly reduced after the application of FFA (Fig. 4C1,D1, Table 1, P, R). Significant reductions in the EPSC duration and frequency by the application of FFA were also observed in INC neurons (Fig. 4C1,D1, Table 1, Q, S). However, the reductions in the EPSC duration and frequency were significantly smaller in INC neurons than in PHN neurons (Fig. 4C3,D3, Table 1, T, U). These results suggest that CAN channels have a weaker contribution to the activation of INC networks than to the activation of PHN networks.

\section{Discussion}

In this study, we investigated the synaptic mechanisms of the sustained activation of excitatory networks that produce position signals in horizontal and vertical oculomotor neural integrators. The activation of excitatory networks in the horizontal integrator was mediated predominantly via CP-AMPA receptors and CAN channels while their activation in the vertical integrator was mediated predominantly via NMDA receptors. Our findings strongly suggest that excitatory networks are activated via different synaptic mechanisms between the horizontal and vertical integrators.

It has been reported that both the PHN and the INC show reciprocal connections with the vestibular nuclei (VNs; Fukushima, 1987; McCrea and Horn, 2006; Leigh and Zee, 2015). The VNs carry eye position signals (Tomlinson and Robinson, 1984; McFarland and Fuchs, 1992), and chemical lesion of the VNs or transection of the connections between the VNs and the integrators induces impairments in gaze holding (Evinger et al., 1977; Cannon and Robinson, 1987; Godaux et al., 1993; Arnold et al., 1999). Therefore, the sustained activity responsible for horizontal and vertical eye position signals may be maintained by reciprocal loops in the PHN-VN and INC-VN networks, respectively (Evinger et al., 1977; Cannon and Robinson, 1987; McFarland and Fuchs, 1992; Sylvestre et al., 2003). Our present and previous studies demonstrated that sustained EPSC responses, indicating local excitatory networks, occurred in reduced preparations in which the connections to the VNs were discontinued (Saito and Yanagawa, 2010; Saito et al., 2017). These findings suggest that recurrent excitatory networks that produce sustained EPSC responses are deployed within the PHN and the INC.

Excitatory networks are inherently leaky. Therefore, when excitatory networks are driven only by fast synaptic transmissions mediated by AMPA receptors, the activity generated by the network is neither sustained nor robust (Seung et al., 2000; Wang, 2001). In the PHN, synaptic transmissions are primarily mediated via AMPA receptors, but $\mathrm{Ca}^{2+}$ influx through CP-AMPA receptors activates CAN channels that generate long-lasting plateau depolarizations (Morisset and Nagy, 1999; Di Prisco et al., 2000; Fransén et al., 2006). The prolonged activity generated by CAN channels can persistently and robustly activate excitatory networks. The present physiologic (RI) and histologic $\left(\mathrm{Co}^{2+}\right.$ uptake) analyses demonstrated that neurons that expressed CP-AMPA receptors existed not only in the PHN but also in the INC. The difference in the neuronal distribution between the PHN and the INC according to the RI suggests that the INC has a smaller proportion of neurons that express CP-AMPA receptors than the PHN. Therefore, the weaker contribution of CP-AMPA receptors in INC networks may be attributed to the small proportion of neurons that express CP-AMPA receptors in the INC. Alternatively, it could be suggested that the majority of neurons that express CP-AMPA receptors in the INC do not participate in the excitatory networks responsible for sustained activity. In this study, a difference in the distribution of neurons that expressed CP-AMPA receptors was not clearly detected in $\mathrm{Co}^{2+}$ uptake experiments. Because KA stimulation activated the excitatory networks too strongly, all PHN and INC neurons that expressed CP-AMPA receptors may have had maximum uptake of $\mathrm{Co}^{2+}$ into their cell bodies. This possible scenario may explain the negative result.

In contrast to the PHN, the sustained EPSC responses in the INC were mediated preferentially via NMDA receptors rather than via a combination of CP-AMPA receptors and CAN channels. NMDA receptors show a slow time course that requires $10-20 \mathrm{~ms}$ to reach the peak and decays over hundreds of milliseconds (Edmonds et al., 1995). This slow time course of the receptors can persistently and robustly activate the INC excitatory networks. Comparison of the NMDA/AMPA ratio revealed that the ratio of INC neurons was higher than the ratio of PHN neurons. In addition, the charge transfer mediated via NMDA receptors was larger in INC neurons than in PHN neurons. These results suggest that the expression of NMDA receptors and/or the conductance of expressed NMDA receptors were higher in INC neurons than in PHN neurons. Studies on cortical pyramidal neurons using 
A

PHN

1 Control
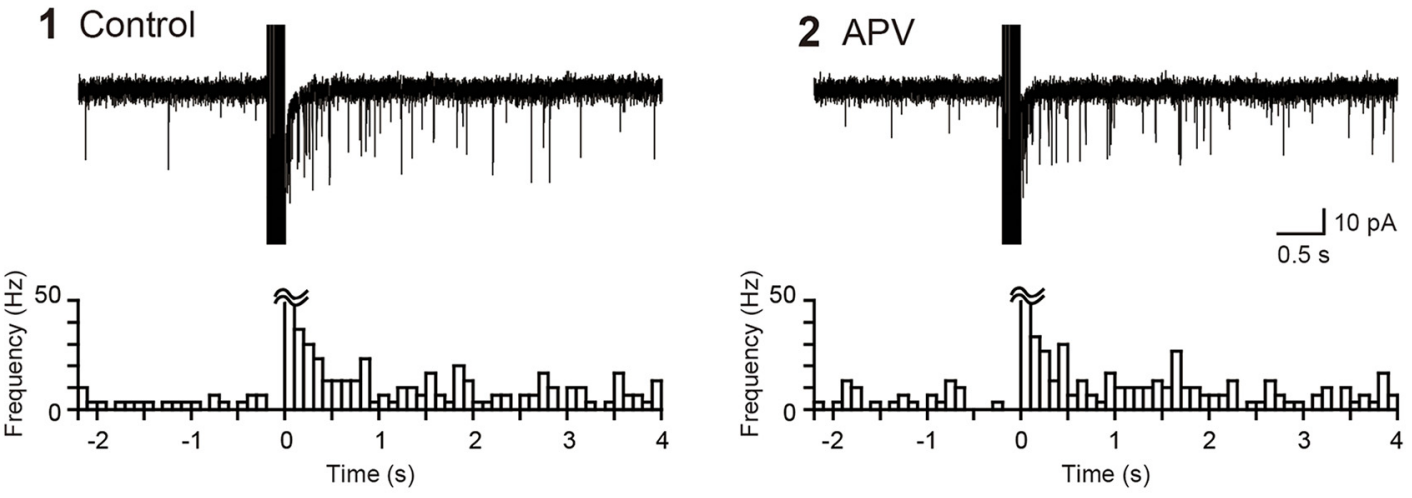

B INC
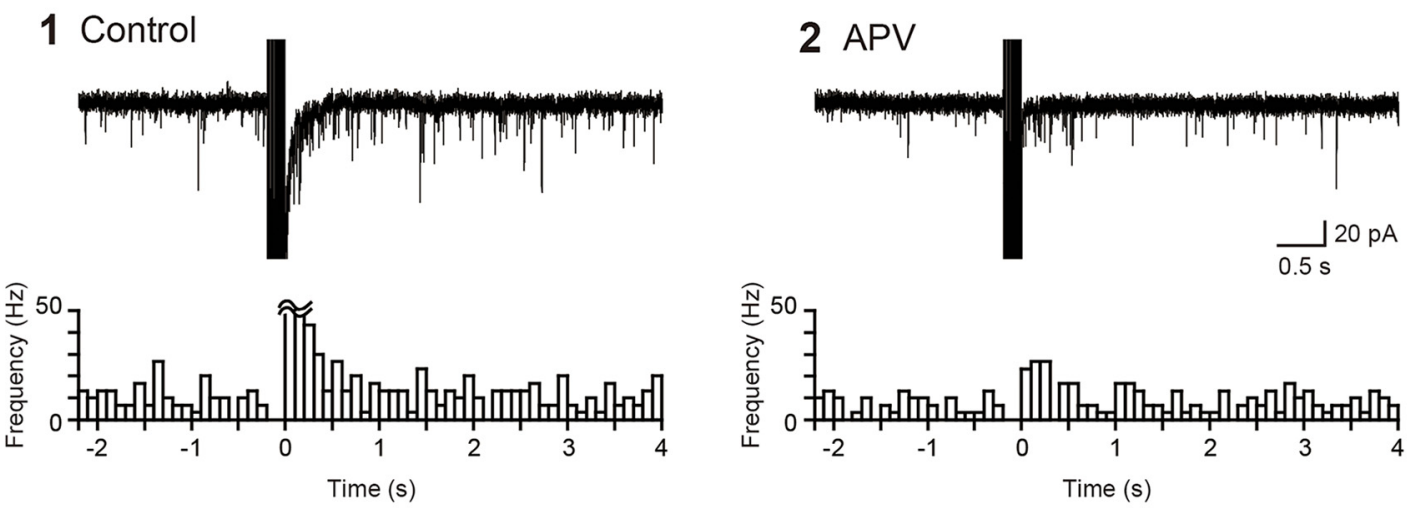

C
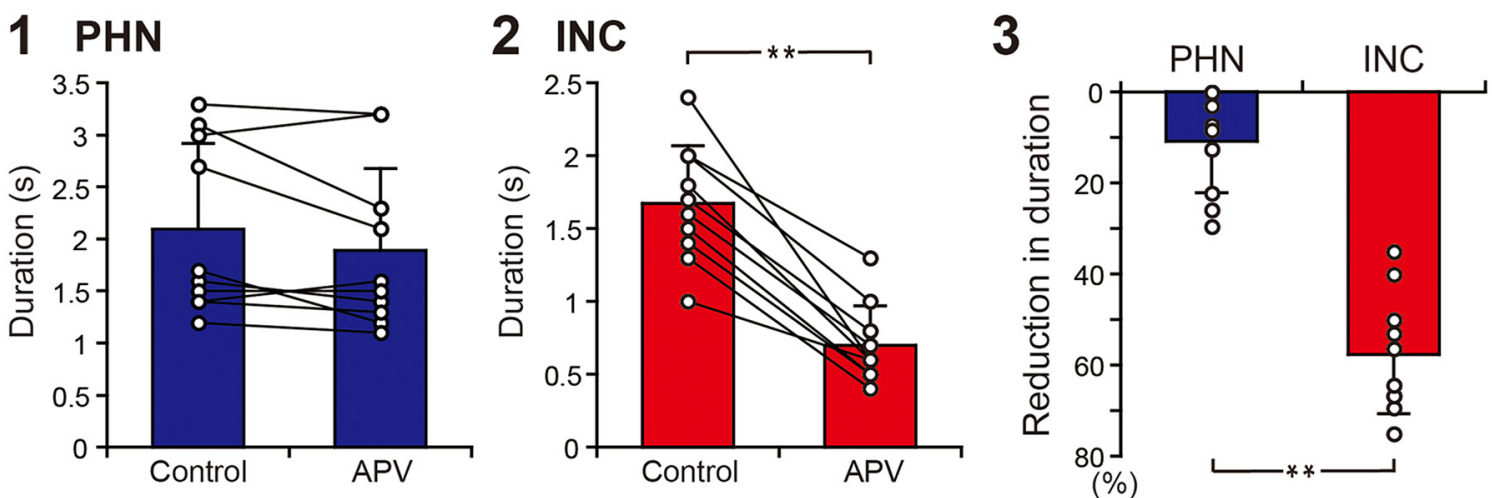

D
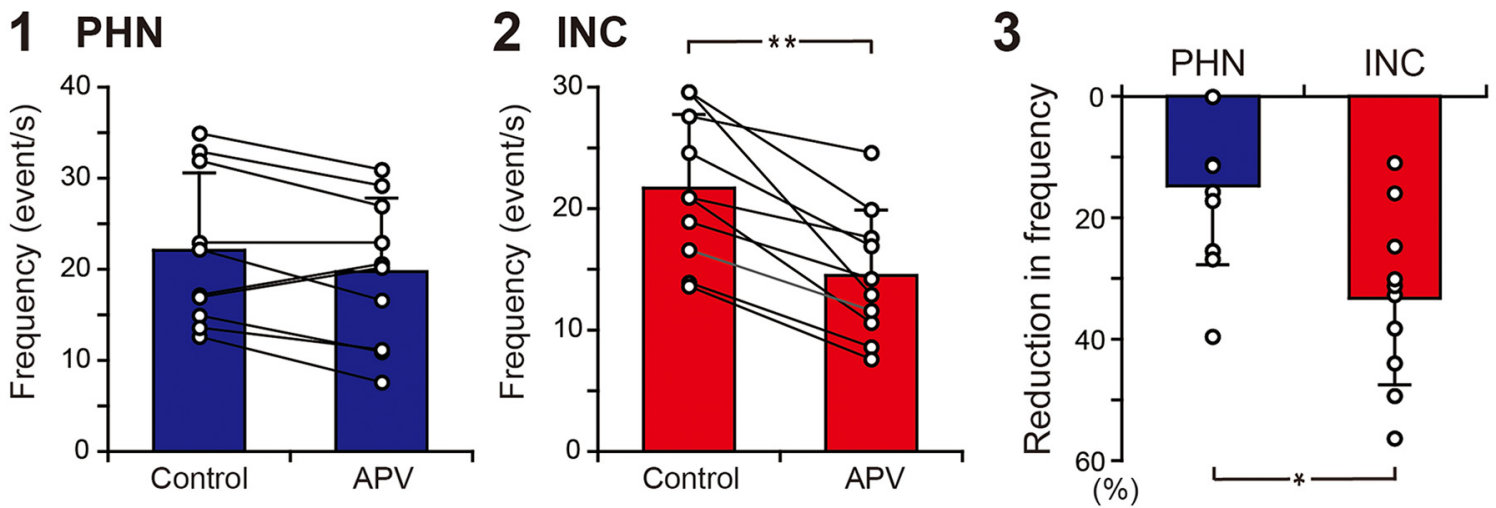

Figure 2. Comparison of the effects of APV on EPSC responses between PHN and INC neurons. A1, $\boldsymbol{A 2}$, EPSC responses of a PHN 
continued

neuron to burst stimulation before $(\boldsymbol{A 1})$ and during $(\boldsymbol{A 2})$ the application of $50 \mu \mathrm{M}$ APV. B1, B2, EPSC responses of an INC neuron to burst stimulation before (B1) and during (B2) APV application. Bottom, Histograms showing the averaged EPSC frequency against time. The width of the histogram bins is $100 \mathrm{~ms}$. C1, C2, Comparison of the duration of the increased EPSC frequency of PHN (C1) and INC (C2) neurons before and during APV application. C3, Comparison of the percentage reduction in the duration caused by APV between PHN and INC neurons. D1, D2, Comparison of the frequency of EPSCs after burst stimulation of PHN (D1) and INC (D2) neurons before and during APV application. D3, Comparison of the percentage reduction in the EPSC frequency caused by APV between PHN and INC neurons. Plots indicate data obtained from individual neurons, and the bar represents the average value. Asterisks indicate a significant difference between groups $(* p<0.05 ; * * p<0.01)$.

caged glutamate or voltage-sensitive dye indicated that NMDA-dependent dendritic plateau depolarization participates in the persistent activity of the neurons (Schiller et al., 2000; Milojkovic et al., 2004). In cortical network models, the larger NMDA/AMPA ratio was found to be involved in the stabilization of persistent activity (Wang, 1999; Compte et al., 2000; Tegnér et al., 2002). In the present study, INC neuron dendrites may have been damaged or truncated during tissue slicing. Therefore, whether dendritic plateau depolarization mediated via NMDA receptors indeed occurs in INC neurons remains an open question.

The EPSC duration and frequency were significantly reduced by FFA in INC neurons, although the effects of

A

1

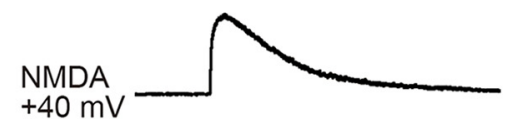

AMPA $-70 \mathrm{mV}$

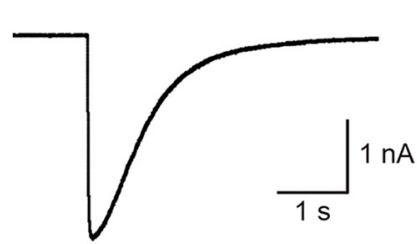

B

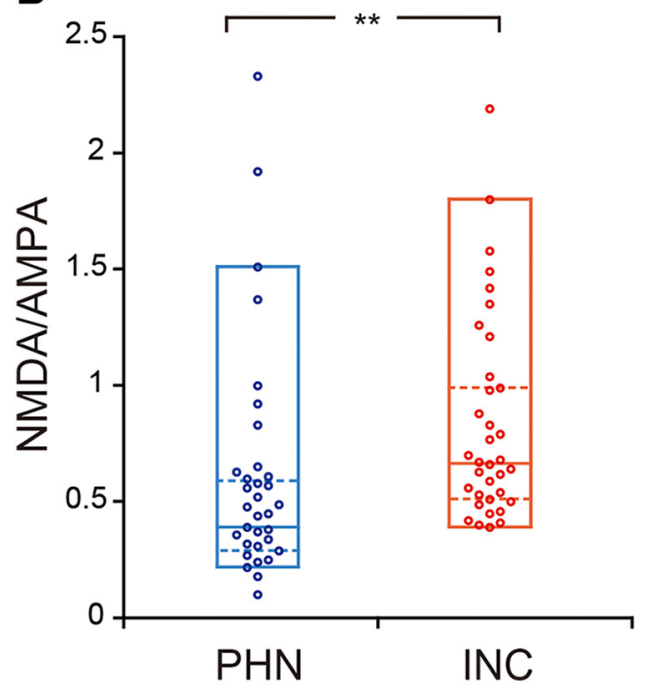

2

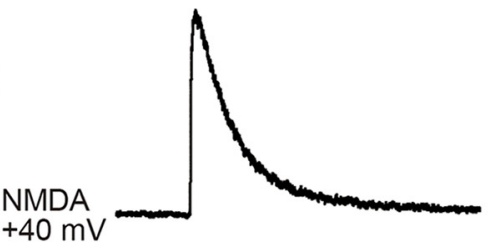

AMPA $-70 \mathrm{mV}$

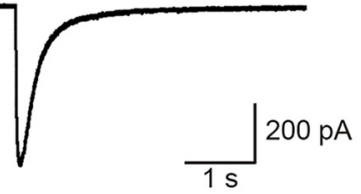

C

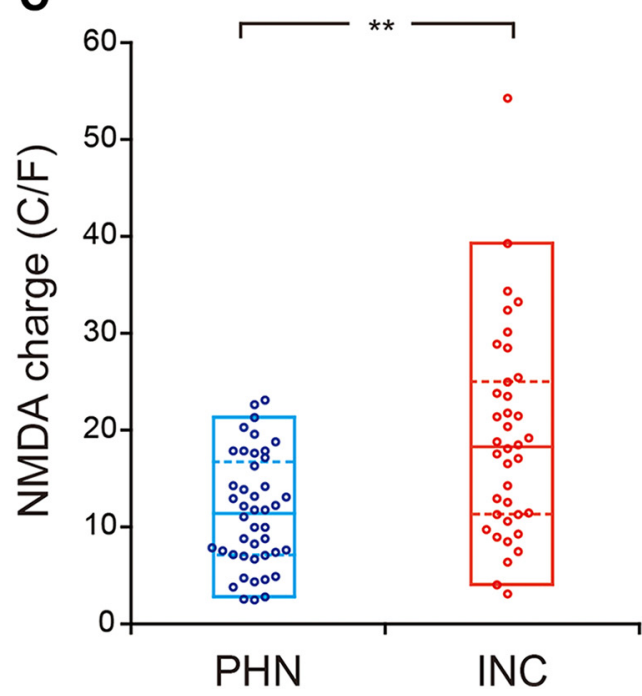

Figure 3. Comparison of NMDA receptor-mediated currents between PHN and INC neurons. $\boldsymbol{A}$, Current traces of two different INC neurons to puff application of $1 \mathrm{~mm}$ kainite at a holding potential of $-70 \mathrm{mV}$ and of $1 \mathrm{~mm}$ NMDA at a holding potential of $+40 \mathrm{mV}$. The NMDA/AMPA ratios of neurons $(\boldsymbol{A 1}, \boldsymbol{A} 2)$ were 0.39 and 1.26 , respectively. $\boldsymbol{B}, \boldsymbol{C}$, Comparisons of the NMDA/AMPA ratio $(\boldsymbol{B})$ and the charge transfer of the NMDA receptor-mediated currents $(\boldsymbol{C})$ between PHN and INC neurons. Plots indicate data obtained from individual neurons. Boxes indicate percentile plots. The bottom and top of each box represent the $5 \%$ and $95 \%$ percentiles of the data, respectively. The middle line in the box represents the median value of the data, whereas the lower and upper dashed lines represent the 25 th and 75 th percentiles of the data, respectively. Asterisks indicate a significant difference between groups $(p<0.01)$. 
A

PHN

1 Control

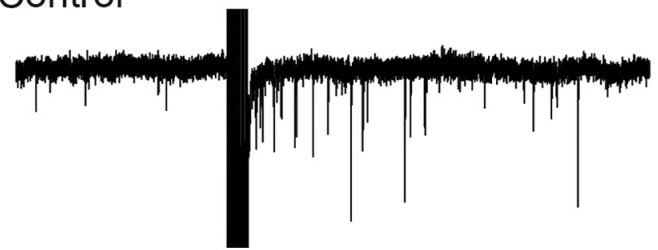

B

INC

1 Control

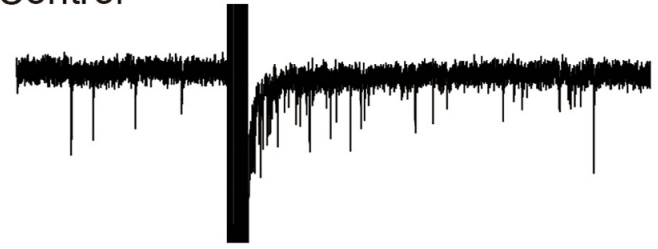

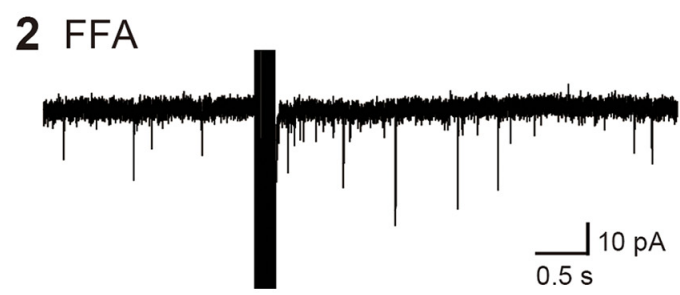

2 FFA

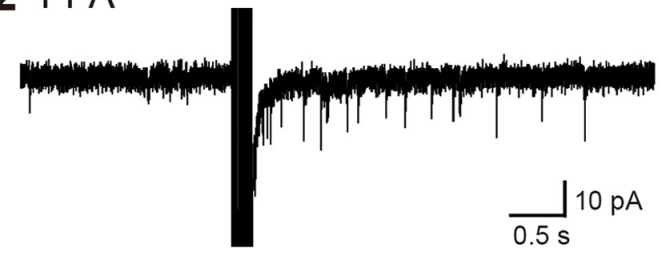

C
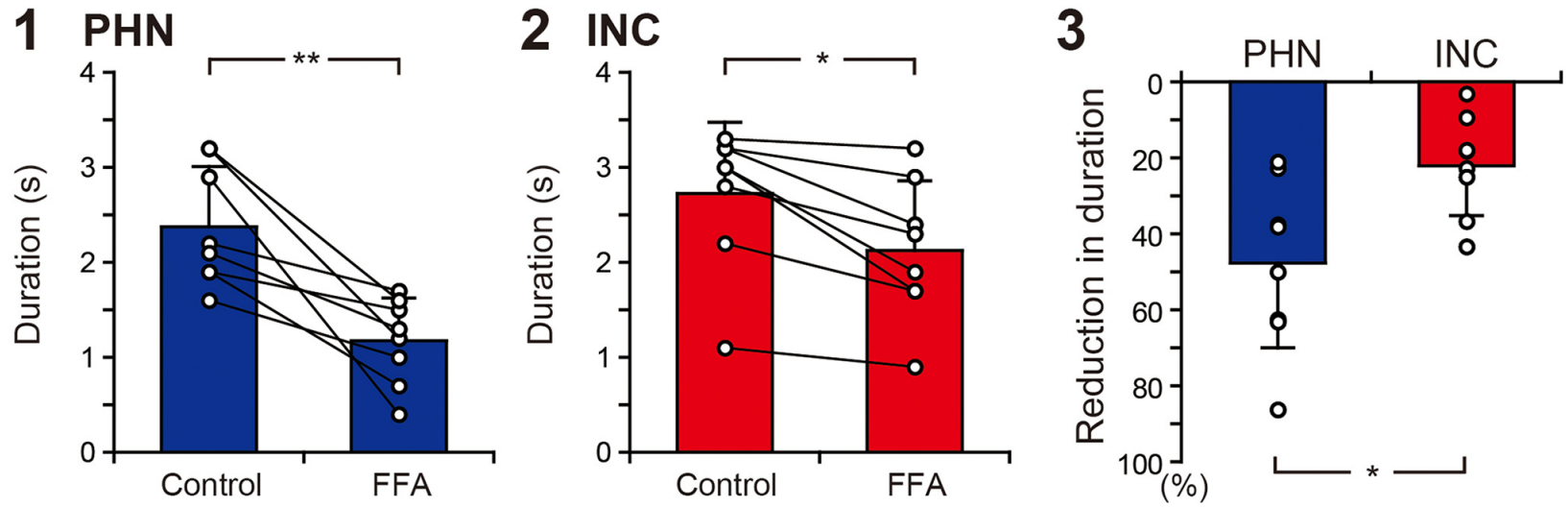

D
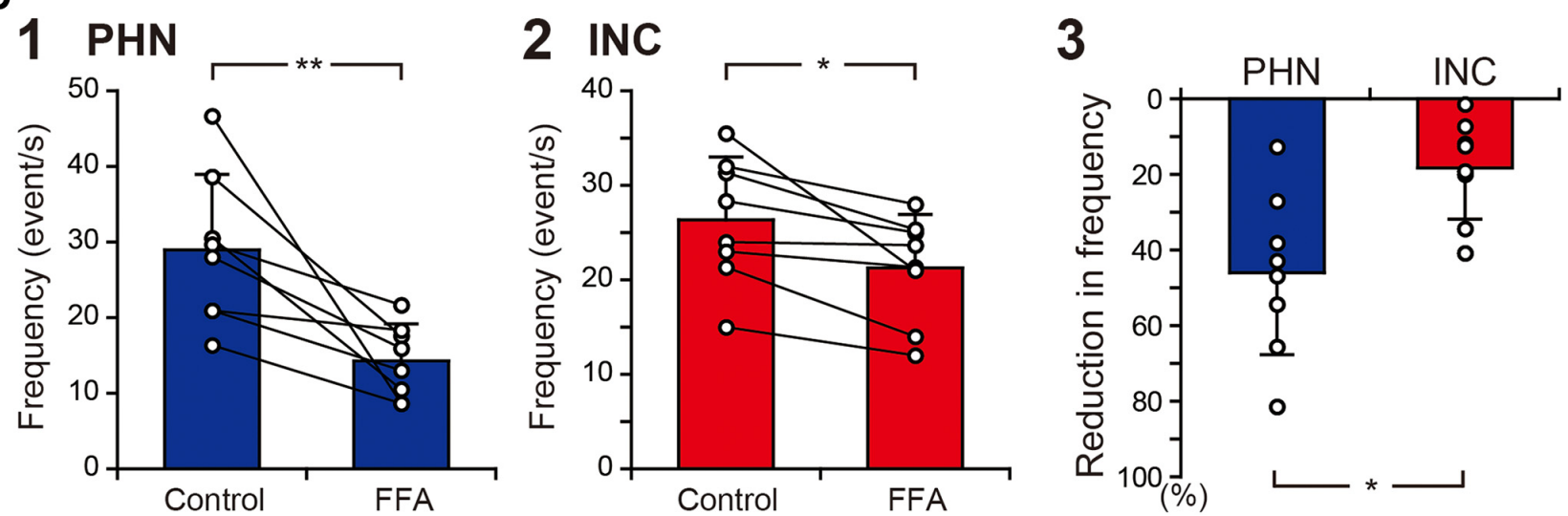

Figure 4. Comparison of the effects of FFA on EPSC responses between PHN and INC neurons. A1, A2, EPSC responses of a PHN neuron to burst stimulation before $(\boldsymbol{A 1})$ and during $(\boldsymbol{A} 2)$ the application of $200 \mu \mathrm{M}$ flufenamic acid (FFA). B1, B2, EPSC responses of an INC neuron to burst stimulation before (B1) and during (B2) FFA application. $\boldsymbol{C 1}, \mathbf{C 2}$, Comparison of the duration of the increased EPSC frequency of PHN (C1) and INC (C2) neurons before and during FFA application. C3, Comparison of the percentage reduction in the duration caused by FFA between PHN and INC neurons. D1, D2, Comparison of the EPSC frequency after the burst stimulation of PHN (D1) and INC (D2) neurons before and during FFA application. D3, Comparison of the percentage reduction in the EPSC frequency caused by FFA between PHN and INC neurons. Plots indicate data obtained from individual neurons, and the bar represents the average value. Asterisks indicate a significant difference between groups $(* p<0.05 ; * * p<0.01)$. 

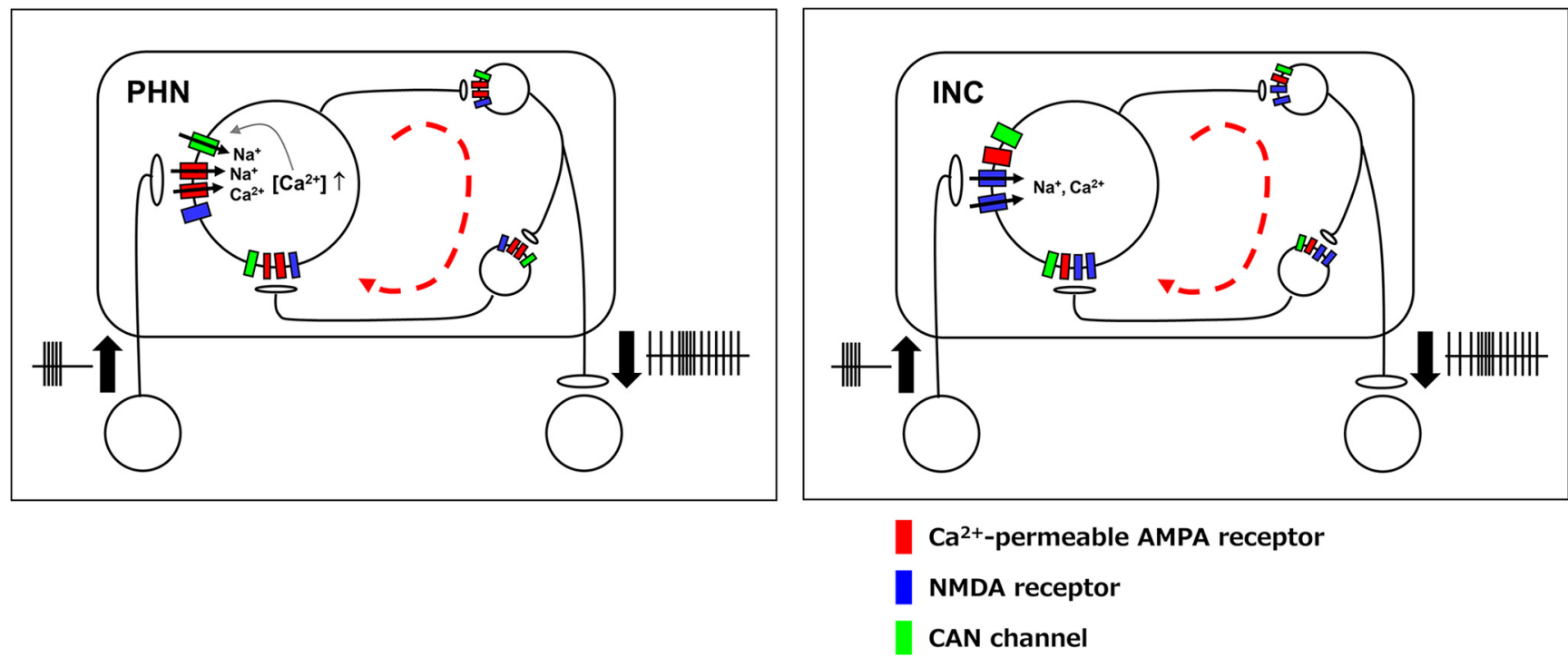

Figure 5. Schematic drawings of the structure of local excitatory circuits in the PHN and the INC. Burst inputs from the premotor areas, such as the pontine reticular formation and the vestibular nucleus, are transformed into tonic outputs to the extraocular motor nuclei by activation of the local excitatory network. Red dashed arrow indicates propagation of excitation.

FFA were significantly smaller in INC neurons than in PHN neurons. This result suggests that CAN channels are partially involved in the activation of INC excitatory networks. Because previous studies have shown the activation of CAN channels by $\mathrm{Ca}^{2+}$ entry through NMDA receptors (Di Prisco et al., 2000; Hall and Delaney, 2002; Zhu et al., 2004), the relationship between CAN channels and NMDA receptors is also considered in INC neurons. However, the effects of FFA were smaller than the effects of APV and were comparable to the effects of NAS (Table 1), suggesting that the activation of CAN channels is implicated in CP-AMPA receptors rather than NMDA receptors in INC neurons.

In the present study, we clarified the different activation mechanisms of local excitatory networks in horizontal and vertical neural integrators. Figure 5 shows the local networks for producing the sustained activity induced in the PHN and the INC. In Figure 5, CP-AMPA receptors and CAN channels are incorporated into all PHN neurons participating in the local networks, and NMDA receptors are incorporated into all INC neurons participating in the networks. However, our previous study on the PHN (Saito and Yanagawa, 2010) showed that the excitatory networks responsible for the sustained EPSC responses included the neurons that did not express CP-AMPA receptors as well as the neurons that expressed the receptors. This finding raises a possibility that some PHN neurons that express CP-AMPA receptors and some INC neurons that express NMDA receptors may play the role of hub neurons that mainly drive sustained activity, although the existence of hub neurons has not been clarified in the PHN or INC. The local excitatory networks themselves may not be sufficient to maintain the activity for gaze holding because the durations of the EPSC responses are shorter than the time constant of the rat neural integrator, which was approximately estimated as a time constant of a centripetal drift after an eye movement to an eccentric direction (Chelazzi et al., 1989). In monkeys, lesions of the commissural inhibitory networks of the neural integrators induced a dramatic reduction in the time constant of the integrators (Arnold and Robinson, 1997), although negative evidence on positive feedback excitation was obtained in goldfish studies (Aksay et al., 2007; Debowy and Baker, 2011). Cerebellar flocculus and paraflocculus inputs modulate the sustained activity of the neural integrators in a positive feedback manner (Zee et al., 1981; Leigh and Zee, 2015). In addition, the sustained depolarization is induced by cholinergic transmissions mediated via muscarinic (Navarro-López et al., 2004, 2005) and nicotinic receptors (Zhang et al., 2016, 2018) in PHN neurons. These modulations of neural activity, in addition to local excitatory networks, can produce the tonic activity sufficient for keeping eyes to an eccentric direction for a moment.

\section{References}

Aksay E, Olasagasti I, Mensh BD, Baker R, Goldman MS, Tank DW (2007) Functional dissection of circuitry in a neural integrator. Nat Neurosci 10:494-504.

Arnold DB, Robinson DA (1997) The oculomotor integrator: testing of a neural network model. Exp Brain Res 113:57-74.

Arnold DB, Robinson DA, Leigh RJ (1999) Nystagmus induced by pharmacological inactivation of the brainstem ocular motor integrator in monkey. Vision Res 39:4286-4295.

Asami T, Kagechika H, Hashimoto Y, Shudo K, Miwa A, Kawai N, Nakajima T (1989) Acylpolyamines mimic the action of joro spider toxin (JSTX) on crustacean muscle glutamate receptors. Biomed Res 10:185-189.

Birch D, Jacobs GH (1979) Spatial contrast sensitivity in albino and pigmented rats. Vision Res 19:933-937.

Burnashev N, Monyer H, Seeburg PH, Sakmann B (1992) Divalent ion permeability of AMPA receptor channels is dominated by the edited form of a single subunit. Neuron 8:189-198. 
Cannon SC, Robinson DA (1985) An improved neural-network model for the neural integrator of the oculomotor system: more realistic neuron behavior. Biol Cybern 53:93-108.

Cannon SC, Robinson DA (1987) Loss of the neural integrator of the oculomotor system from brain stem lesions in monkey. J Neurophysiol 57:1383-1409.

Cannon SC, Robinson DA, Shamma S (1983) A proposed neural network for the integrator of the oculomotor system. Biol Cybern 49:127-136.

Chelazzi L, Rossi F, Tempia F, Ghirardi M, Strata P (1989) Saccadic eye movements and gaze holding in the head-restrained pigmented rat. Eur J Neurosci 1:639-646.

Compte A, Brunel N, Goldman-Rakic PS, Wang XJ (2000) Synaptic mechanisms and network dynamics underlying spatial working memory in a cortical network model. Cereb Cortex 10:910-923.

Debowy O, Baker R (2011) Encoding of eye position in the goldfish horizontal oculomotor neural integrator. J Neurophysiol 105:896909.

Di Prisco VG, Pearlstein E, Le Ray D, Robitaille R, Dubuc R (2000) A cellular mechanism for the transformation of a sensory input into a motor command. J Neurosci 20:8169-8176.

Draye JP, Cheron G, Libert G, Godaux E (1997) Emergence of clusters in the hidden layer of a dynamic recurrent neural network. Biol Cybern 76:365-374.

Edmonds B, Gibb AJ, Colquhoun D (1995) Mechanisms of activation of glutamate receptors and the time course of excitatory synaptic currents. Annu Rev Physiol 57:495-519.

Engelman HS, Allen TB, MacDermott AB (1999) The distribution of neurons expressing calcium-permeable AMPA receptors in the superficial laminae of the spinal cord dorsal horn. J Neurosci 19:2081-2089.

Evinger LC, Fuchs AF, Baker R (1977) Bilateral lesions of the medial longitudinal fasciculus in monkeys: effects on the horizontal and vertical components of voluntary and vestibular induced eye movements. Exp Brain Res 28:1-20.

Faul F, Erdfelder E, Lang AG, Buchner A (2007) G*Power 3: a flexible statistical power analysis program for the social, behavioral, and biomedical sciences. Behav Res Methods 39:175-191.

Fransén E, Tahvildari B, Egorov AV, Hasselmo ME, Alonso AA (2006) Mechanism of graded persistent cellular activity of entorhinal cortex layer $V$ neurons. Neuron 49:735-746.

Fukushima K (1987) The interstitial nucleus of Cajal and its role in the control of movements of head and eyes. Prog Neurobiol 29:107192.

Fukushima K (1991) The interstitial nucleus of Cajal in the midbrain reticular formation and vertical eye movement. Neurosci Res 10: 159-87.

Fukushima K, Kaneko CR (1995) Vestibular integrators in the oculomotor system. Neurosci Res 22:249-259.

Fukushima K, Kaneko CR, Fuchs AF (1992) The neuronal substrate of integration in the oculomotor system. Prog Neurobiol 39:609-639.

Galiana HL, Outerbridge JS (1984) A bilateral model for central neural pathways in vestibuloocular reflex. J Neurophysiol 51:210-241.

Godaux E, Mettens P, Cheron G (1993) Differential effect of injections of kainic acid into the prepositus and the vestibular nuclei of the cat. J Physiol 472:459-482.

Hall BJ, Delaney KR (2002) Contribution of a calcium-activated non-specific conductance to NMDA receptor-mediated synaptic potentials in granule cells of the frog olfactory bulb. J Physiol 543:819-834.

Hume RI, Dingledine R, Heinemann SF (1991) Identification of a site in glutamate receptor subunits that controls calcium permeability. Science 253:1028-1031.

lino M, Ozawa S, Tsuzuki K (1990) Permeation of calcium through excitatory amino acid receptor channels in cultured rat hippocampal neurones. J Physiol 424:151-165.

Jonas P, Burnashev N (1995) Molecular mechanisms controlling calcium entry through AMPA-type glutamate receptor channels. Neuron 15:987-990.
Joshua M, Lisberger SG (2015) A tale of two species: Neural integration in zebrafish and monkeys. Neuroscience 296:80-91.

Kiskin NI, Krishtal OA, AYa T (1986) Excitatory amino acid receptors in hippocampal neurons: kainate fails to desensitize them. Neurosci Lett 63:225-230.

Koike M, lino M, Ozawa S (1997) Blocking effect of 1-naphthyl acetyl spermine on $\mathrm{Ca}(2+)$-permeable AMPA receptors in cultured rat hippocampal neurons. Neurosci Res 29:27-36.

Leigh RJ, Zee DS (2015) The neurology of eye movements. Oxford: Oxford UP.

McCrea RA, Horn AK (2006) Nucleus prepositus. Prog Brain Res 151:205-230.

McFarland JL, Fuchs AF (1992) Discharge patterns in nucleus prepositus hypoglossi and adjacent medial vestibular nucleus during horizontal eye movement in behaving macaques. J Neurophysiol 68:319-332.

Milojkovic BA, Radojicic MS, Goldman-Rakic PS, Antic SD (2004) Burst generation in rat pyramidal neurones by regenerative potentials elicited in a restricted part of the basilar dendritic tree. $J$ Physiol 558:193-211.

Morisset V, Nagy F (1999) lonic basis for plateau potentials in deep dorsal horn neurons of the rat spinal cord. J Neurosci 19:73097316.

Moschovakis AK (1997) The neural integrators of the mammalian saccadic system. Front Biosci 2:d552-577.

Navarro-López Jde D, Alvarado JC, Márquez-Ruiz J, Escudero M, Delgado-García JM, Yajeya J (2004) A cholinergic synaptically triggered event participates in the generation of persistent activity necessary for eye fixation. J Neurosci 24:5109-5118.

Navarro-López Jde D, Delgado-García JM, Yajeya J (2005) Cooperative glutamatergic and cholinergic mechanisms generate shortterm modifications of synaptic effectiveness in prepositus hypoglossi neurons. J Neurosci 25:9902-9906.

Ozawa S, lino M (1993) Two distinct types of AMPA responses in cultured rat hippocampal neurons. Neurosci Lett 155:187-190.

Ozawa S, lino M, Tsuzuki K (1991) Two types of kainate response in cultured rat hippocampal neurons. J Neurophysiol 66:2-11.

Ozawa S, Kamiya H, Tsuzuki K (1998) Glutamate receptors in the mammalian central nervous system. Prog Neurobiol 54:581-618.

Patneau DK, Mayer ML (1991) Kinetic analysis of interactions between kainate and AMPA: evidence for activation of a single receptor in mouse hippocampal neurons. Neuron 6:785-798.

Prusky GT, Harker KT, Douglas RM, Whishaw IQ (2002) Variation in visual acuity within pigmented, and between pigmented and albino rat strains. Behav Brain Res 136:339-348.

Pruss RM, Akeson RL, Racke MM, Wilburn JL (1991) Agonistactivated cobalt uptake identifies divalent cation-permeable kainate receptors on neurons and glial cells. Neuron 7:509-518.

Robinson DA (1975) Oculomotor control signals. In: Basic mechanisms of ocular motility and their clinical implications (Lennerstrand G, Bach-y-Rita P, eds), pp 337-374. Oxford: Pergamon.

Robinson DA (1989) Integrating with neurons. Ann Rev Neurosci 12:33-45.

Saito Y, Yanagawa $Y(2010)$ Synaptic mechanism for the sustained activation of oculomotor integrator circuits in the rat prepositus hypoglossi nucleus: contribution of $\mathrm{Ca}^{2+}$-permeable AMPA receptors. J Neurosci 30:15735-15746.

Saito Y, Sugimura T, Yanagawa Y (2017) Comparisons of neuronal and excitatory network properties between the rat brainstem nuclei that participate in vertical and horizontal gaze holding. eNeuro 4:ENEURO.0180-17.2017.

Schiller J, Major G, Koester HJ, Schiller Y (2000) NMDA spikes in basal dendrites of cortical pyramidal neurons. Nature 404:285289.

Seung HS, Lee DD, Reis BY, Tank DW (2000) Stability of the memory of eye position in a recurrent network of conductance-based model neurons. Neuron 26:259-271.

Shimshek DR, Jensen V, Celikel T, Geng Y, Schupp B, Bus T, Mack V, Marx V, Hvalby Ø, Seeburg PH, Sprengel R (2006) Forebrainspecific glutamate receptor $B$ deletion impairs spatial memory but 
not hippocampal field long-term potentiation. J Neurosci 26:84288440.

Skavenski AA, Robinson DA (1973) Role of abducens neurons in vestibuloocular reflex. J Neurophysiol 36:724-738.

Sylvestre PA, Choi JT, Cullen KE (2003) Discharge dynamics of oculomotor neural integrator neurons during conjugate and disjunctive saccades and fixation. J Neurophysiol 90:739-754.

Takazawa A, Yamazaki O, Kanai H, Ishida N, Kato N, Yamauchi T (1996) Potent and long-lasting anticonvulsant effects of 1-naphthylacetyl spermine, an analogue of Joro spider toxin, against amygdaloid kindled seizures in rats. Brain Res 706:173-176.

Tegnér J, Compte A, Wang XJ (2002) The dynamical stability of reverberatory neural circuits. Biol Cybern 87:471-481.

Tomlinson RD, Robinson DA (1984) Signals in vestibular nucleus mediating vertical eye movements in the monkey. J Neurophysiol 51:1121-1136.

Twomey EC, Yelshanskaya MV, Vassilevski AA, Sobolevsky Al (2018) Mechanisms of channel block in calcium-permeable AMPA receptors. Neuron 99:956-968.
Wang X-J (1999) Synaptic basis of cortical persistent activity: the importance of NMDA receptors to working memory. J Neurosci 19:9587-9603.

Wang X-J (2001) Synaptic reverberation underlying mnemonic persistent activity. Trends Neurosci 24:455-463.

Zee DS, Yamazaki A, Butler PH, Gücer G (1981) Effects of ablation of flocculus and paraflocculus of eye movements in primate. J Neurophysiol 46:878-899.

Zhang Y, Yanagawa Y, Saito Y (2016) Nicotinic acetylcholine receptor-mediated responses in medial vestibular and prepositus hypoglossi nuclei neurons showing distinct neurotransmitter phenotypes. J Neurophysiol 115:2649-2657.

Zhang Y, Yanagawa Y, Saito Y (2018) Firing responses mediated via distinct nicotinic acetylcholine receptor subtypes in rat prepositus hypoglossi nuclei neurons. J Neurophysiol 120:1525-1533.

Zhu ZT, Munhall A, Shen KZ, Johnson SW (2004) Calciumdependent subthreshold oscillations determine bursting activity induced by $\mathrm{N}$-methyl-D-aspartate in rat subthalamic neurons in vitro. Eur J Neurosci 19:1296-1304. 